\title{
Preliminary Identification of a Possible Cell-division Protein in the Cyanobacterium Anacystis nidulans
}

\author{
By HANS CHRISTIAN UTKILEN ${ }^{1 *}$ AND OLE-MARTIN GULLIKSEN ${ }^{2}$ \\ ${ }^{1}$ Botanical Institute, P.O. Box 1045 and ${ }^{2}$ Zoological Institute, P.O. Box 1050, \\ University of Oslo, Blindern, Oslo 3, Norway
}

(Received 26 October 1982; revised 14 December 1982)

\begin{abstract}
Cultures of the cyanobacterium Anacystis nidulans were grown under conditions of $\mathrm{Mg}^{2+}$ limitation and $\mathbf{M g}^{2+}$-excess. Cell-free extracts, obtained after sonication and centrifugation $(45000 \mathrm{~g}, 60 \mathrm{~min})$, were analysed on polyacrylamide gels. $\mathrm{Mg}^{2+}-$ limited cells, in which cell division was inhibited, accumulated a protein of molecular weight $50 \times 10^{3}$. Only small amounts of this protein were detected in non- $\mathrm{Mg}^{2+}$-limited cultures. A protein of molecular weight $36 \times 10^{3}$, found in non- $\mathrm{Mg}^{2+}$-limited cells, was not detected in $\mathrm{Mg}^{2+}$-limited cells. When a $\mathrm{Mg}^{2+}$ shift-up from $5 \mu \mathrm{M}$ to $1 \mathrm{mM}$ was carried out in a chemostat, synthesis of the $36 \times 10^{3}$ protein was initiated and the amount of the $50 \times 10^{3}$ protein decreased whilst the main protein pattern remained unaltered. The possibility that the two proteins are involved in cell division is discussed.
\end{abstract}

\section{INTRODUCTION}

In $\mathrm{Mg}^{2+}$-limited chemostats the cyanobacterium Anacystis nidulans grows as filaments without septa or transverse walls. In batch cultures an increase in the $\mathrm{Mg}^{2+}$ concentration from $5 \mu \mathrm{M}$ to $1 \mathrm{mM}$ results in a synchronized division of the filaments into smaller cells about $90 \mathrm{~min}$ after the elevation of the $\mathrm{Mg}^{2+}$ concentration (Utkilen, 1982). This synchronized cell division occurs without a change in overall rates of DNA or protein synthesis, but protein synthesis has been shown to be necessary to obtain the cell division (Utkilen, 1982). It has also been shown (Mann \& Carr, 1977) that protein synthesis occurring at the termination of DNA replication is required for cell division to take place in $A$. nidulans.

Evidence from other prokaryotes suggests that septal formation and cell division require synthesis of specific proteins (Inouye \& Pardee, 1970; Smith \& Pardee, 1970; Ahmed \& Rowbury, 1971; Grula \& King, 1971 ; Ingram \& Fisher, 1973). In this paper we present evidence that $\mathrm{Mg}^{2+}$-limitation prevents accumulation of a specific protein and enhances the accumulation of another. Both these proteins may be concerned with cell division.

\section{METHODS}

Organism. Anacystis nidulans strain UTEX 625 of the Culture Collection of Algae, Department of Botany, University of Texas, was used.

Growth conditions. The continuous cultures have been described earlier (Utkilen, 1982); they were fed with the modified medium $\mathrm{C}$ (Utkilen, 1982) containing $5 \mu \mathrm{M}-\mathrm{Mg}^{2+}$. The growth temperature was $40^{\circ} \mathrm{C}$ and the dilution rate $(D) 0.09 \mathrm{~h}^{-1}$. The culture vessel was placed between two ranks of fluorescent tubes (Utkilen, 1982), which gave an incident light intensity of $445 \mu \mathrm{E} \mathrm{m}^{-2} \mathrm{~s}^{-1}(32.5 \mathrm{klx})$ at both sides of the culture vessel. This was the light intensity used during $\mathrm{Mg}^{2+}$-limited growth, where the mean cell volume was about $2 \mu \mathrm{m}^{3}$. At light intensities of $108 \mu \mathrm{E} \mathrm{m}^{-2} \mathrm{~s}^{-1}(7.6 \mathrm{klx})$ or lower, the mean cell volume in the same culture was about $0.9 \mu \mathrm{m}^{3}$. This is the cell size obtained when $\mathrm{Mg}^{2+}$ is not limiting cell division (Utkilen, 1982). Therefore $108 \mu \mathrm{E} \mathrm{m}^{-2} \mathrm{~s}^{-1}$ was used to obtain 'normal' cell division under the same growth conditions and this is referred to as a 'non- $\mathbf{M g}^{2+}-$ limited culture' in 
this work. The light intensity was measured by LI 1854 Quantum/Radiometer/Photometer (Lambda Instruments Corporation, U.S.A.) and it was altered by placing white paper sheets between the fluorescent tubes and the waterbath.

Magnesium shift-up experiments in the continuous culture were carried out by increasing the $\mathbf{M g}^{2+}$ concentration in the growth vessel to $1 \mathrm{mM}$, by adding $\mathrm{MgCl}_{2}$, and changing the reservoir to one with medium containing $1 \mathrm{mM}-\mathrm{Mg}^{2+}$.

Non- $\mathrm{Mg}^{2+}-$ limited batch cultures were grown in Roux flasks containing $800 \mathrm{ml}$ of the above medium with the $\mathrm{Mg}^{2+}$ concentration increased to $1 \mathrm{~mm}$ by adding $\mathrm{MgCl}_{2}$. The Roux flasks were placed in the same waterbath as that used for the continuous cultures, and were aerated with the same air/ $/ \mathrm{CO}_{2}(95: 5, \mathrm{v} / \mathrm{v}) \mathrm{mixt}$ ture as the other cultures. The specific growth rate under these conditions was about $0 \cdot 2 \mathrm{~h}^{-1}$, and the cells were always harvested during exponential growth.

Protein extraction and sample preparation. Cells were harvested by centrifugation $(10000 \mathrm{~g}, 10 \mathrm{~min})$, washed once with distilled water and stored frozen at $-20^{\circ} \mathrm{C}$. The frozen cells $(15-20 \mathrm{mg}$ dry weight), resuspended in $0 \cdot 5-$

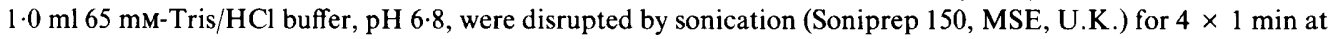
$0{ }^{\circ} \mathrm{C}$ and centrifuged $(45000 \mathrm{~g}, 60 \mathrm{~min})$. Sucrose, SDS, dithiothreitol and Bromophenol Blue were added to the supernatant to give final concentrations $(\mathrm{w} / \mathrm{v})$ of $15 \%, 2 \%, 2 \%$ and $0.001 \%$, respectively. The mixture was heated at $100^{\circ} \mathrm{C}$ for $5 \mathrm{~min}$ before loading on the SDS-PAGE gels.

For isoelectric focusing, protein samples were prepared essentially according to O'Farrell (1975) with the modifications of Petersen et al. (1979).

Protein concentrations were determined by the Lowry method using bovine serum albumin (Sigma) as standard.

One- and two-dimensional gel electrophoresis. SDS-PAGE on a $8-18 \%(\mathrm{w} / \mathrm{v})$ linear gradient slab gel was run according to Laemmli (1970) with one modification: the ratio of acrylamide : $N, N^{\prime}$-methylenebisacrylamide was $44: 0 \cdot 8$ in the separating gel. The gels were fixed overnight in $50 \%(\mathrm{v} / \mathrm{v})$ methanol, $10 \%(\mathrm{v} / \mathrm{v})$ acetic acid, stained for $3 \mathrm{~h}$ with Coomassie Brilliant Blue $(0 \cdot 1 \%$ in fixative) and destained by diffusion in the same fixative. Bio-Rad's low molecular weight markers were used as standards for molecular weight determinations. The gels were scanned at $570 \mathrm{~nm}$ in a Gilford 240 spectrophotometer with the corresponding linear transport attached.

Isoelectric focusing and two-dimensional gel electrophoresis was carried out according to O'Farrell (1975) with the $8-18 \%(w / v)$ linear gradient as the second dimension gel. The proteins on these gels were visualized with the silver staining method as described by Oakley et al. (1980).

\section{RESULTS AND DISCUSSION}

The electrophoretic band pattern of proteins from extracts of $A$. nidulans grown in $\mathrm{Mg}^{2+}$ limited and non- $\mathrm{Mg}^{2+}$-limited continuous cultures, and in non-limited batch cultures, showed several quantitative differences (Fig. 1). Most of these differences were presumably due to the variation in growth conditions, as can be seen for the phycocyanin (PC in Fig. 1). Extracts from the low light $\left(108 \mu \mathrm{E} \mathrm{m}^{-2} \mathrm{~s}^{-1}\right)$ culture contained more of this light-harvesting protein than those from the two other cultures and they were easily identified by their blue colour even during electrophoresis.

When looking for obvious differences between the extracts from the filamentous cells $\left(\mathrm{Mg}^{2+}\right.$ limited), where the mean cell volume was about $2 \mu \mathrm{m}^{3}$, and both extracts from the 'normal-sized' cells, where the mean cell volume was $0.9 \mu \mathrm{m}^{3}$, two protein bands, $X$ and $Y$ (Fig. 1), were suspected to be connected with cell division. Band X-protein was found in the extracts from non$\mathrm{Mg}^{2+}$-limited continuous and batch cultures, but it was missing from the extract from $\mathrm{Mg}^{2+}$ limited cells. Band Y-protein, which accumulated in the filamentous $\mathrm{Mg}^{2+}$-limited cells, was missing or was present at a low concentration in the extracts from the other cultures. X- and Yproteins had molecular weights of $36 \times 10^{3}$ and $50 \times 10^{3}$, respectively (Fig. 1).

Gel patterns of the non-soluble proteins remaining in the pellets after the $45000 \mathrm{~g}, 60 \mathrm{~min}$ centrifugation showed no differences in protein composition between the $\mathbf{M g}^{2+}$-limited and non- $\mathrm{Mg}^{2+}$-limited cells (results not shown).

By using two-dimensional gel electrophoresis and visualizing the proteins with silver staining, 300-400 proteins were detected, but only a few differences in protein patterns were found between the non- $\mathrm{Mg}^{2+}$-limited and $\mathrm{Mg}^{2+}$-limited continuous cultures (Fig. 2). The most obvious difference was a protein located at the same position as the band X-protein in Fig. 1, which in Fig. 2 also is missing from the $\mathrm{Mg}^{2+}$-limited cultures. This protein was therefore identified as band $\mathrm{X}$-protein; it had a $\mathrm{pI}$ value of 5.3. It is also possible to locate the $\mathrm{Y}$-protein in Fig. 2, since a 


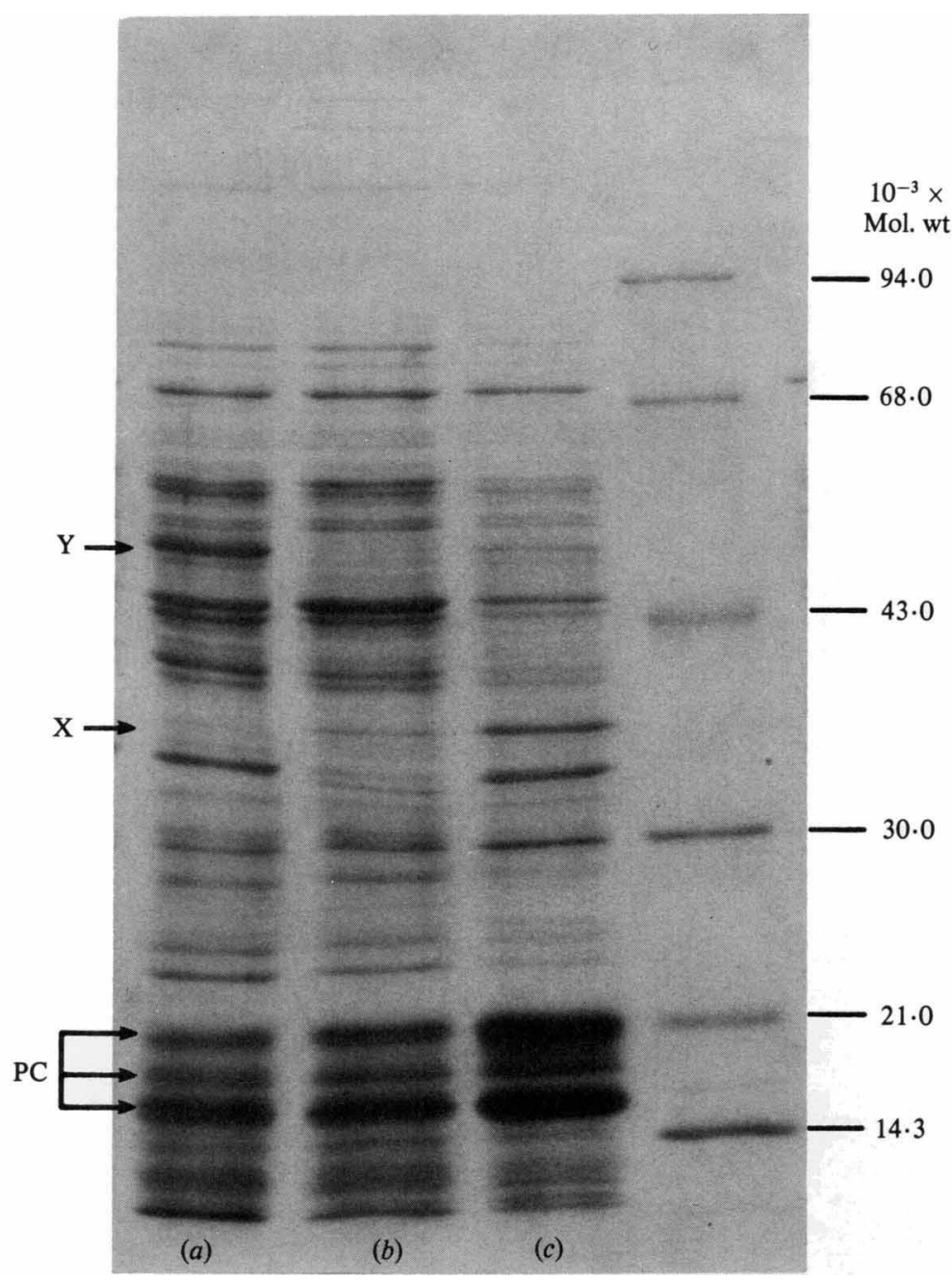

Fig. 1. SDS-PAGE of supernatants from crude extracts of $\boldsymbol{A}$. nidulans grown in $(a) \mathrm{Mg}^{2+}-$ limited and (c) non- $\mathrm{Mg}^{2+}-$ limited continuous cultures at $D=0.09 \mathrm{~h}^{-1}$, and in $(b)$ a non-limited batch culture. The proteins thought to be influenced by $\mathrm{Mg}^{2+}$ are marked $\mathrm{X}$ and $\mathrm{Y}$, and $\mathrm{PC}$ marks the phycocyanin. The molecular weight markers used are, from top to bottom: phosphorylase B, bovine serum albumin, ovalbumin, carbonic anhydrase, soybean trypsin inhibitor and lysozyme. Each sample contained $50 \mu \mathrm{g}$ protein.

protein found in the same position as the band Y-protein in Fig. 1 was present in much larger quantities in the extracts from $\mathrm{Mg}^{2+}$-limited cells (Fig. $2 b$ ) than in that from the non- $\mathrm{Mg}^{2+}$ limited cells (Fig. $2 a$ ). This protein had a pI value of $5 \cdot 4$.

It is possible that proteins $\mathrm{X}$ and $\mathrm{Y}$ are connected with cell division in A. nidulans, but the only evidence from the experiments so far was their presence or absence in the filamentous cells. One way to obtain better evidence for a possible link between cell division and the two proteins was to initiate cell division in the filamentous cells and look for alterations in the protein bands. A $\mathrm{Mg}^{2+}$ shift-up from $5 \mu \mathrm{M}$ to $1 \mathrm{mM}$ has been shown to induce a synchronized cell division in filamentous $A$. nidulans, while the rate of protein synthesis was not affected by this treatment (Utkilen, 1982). Thus, a $\mathrm{Mg}^{2+}$ shift-up initiated cell division without altering the main protein pattern and therefore variations in only the band $\mathrm{X}$ - and $\mathrm{Y}$-proteins might be found if these proteins are indeed connected with septum formation and cell division. When a similar $\mathbf{M g}^{2+}$ 


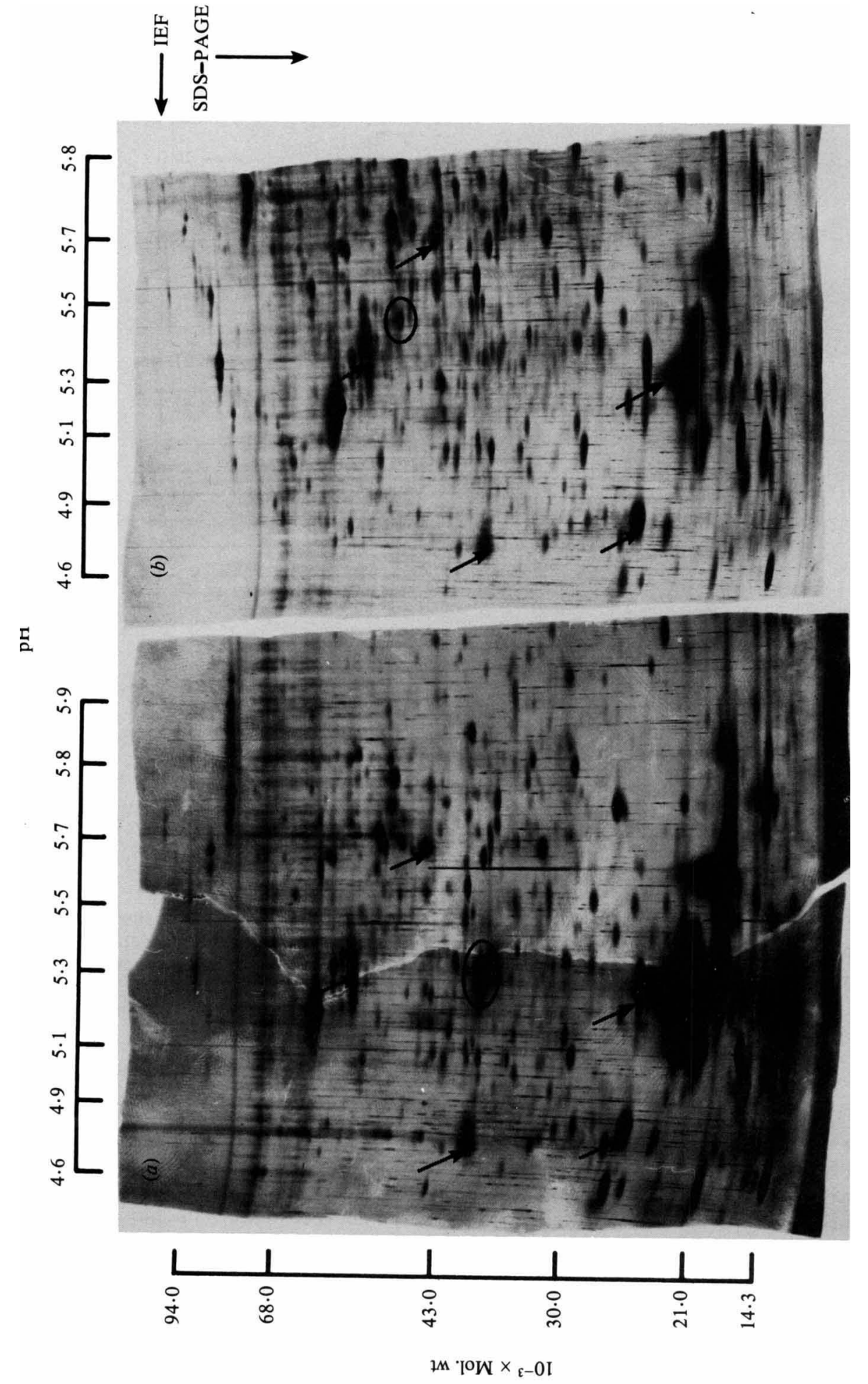

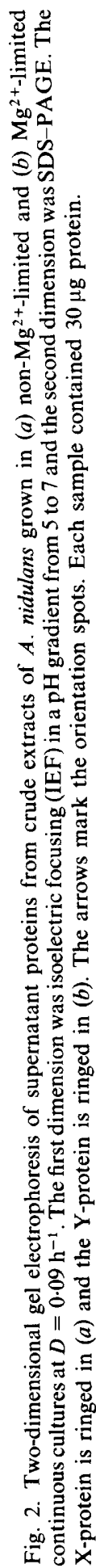




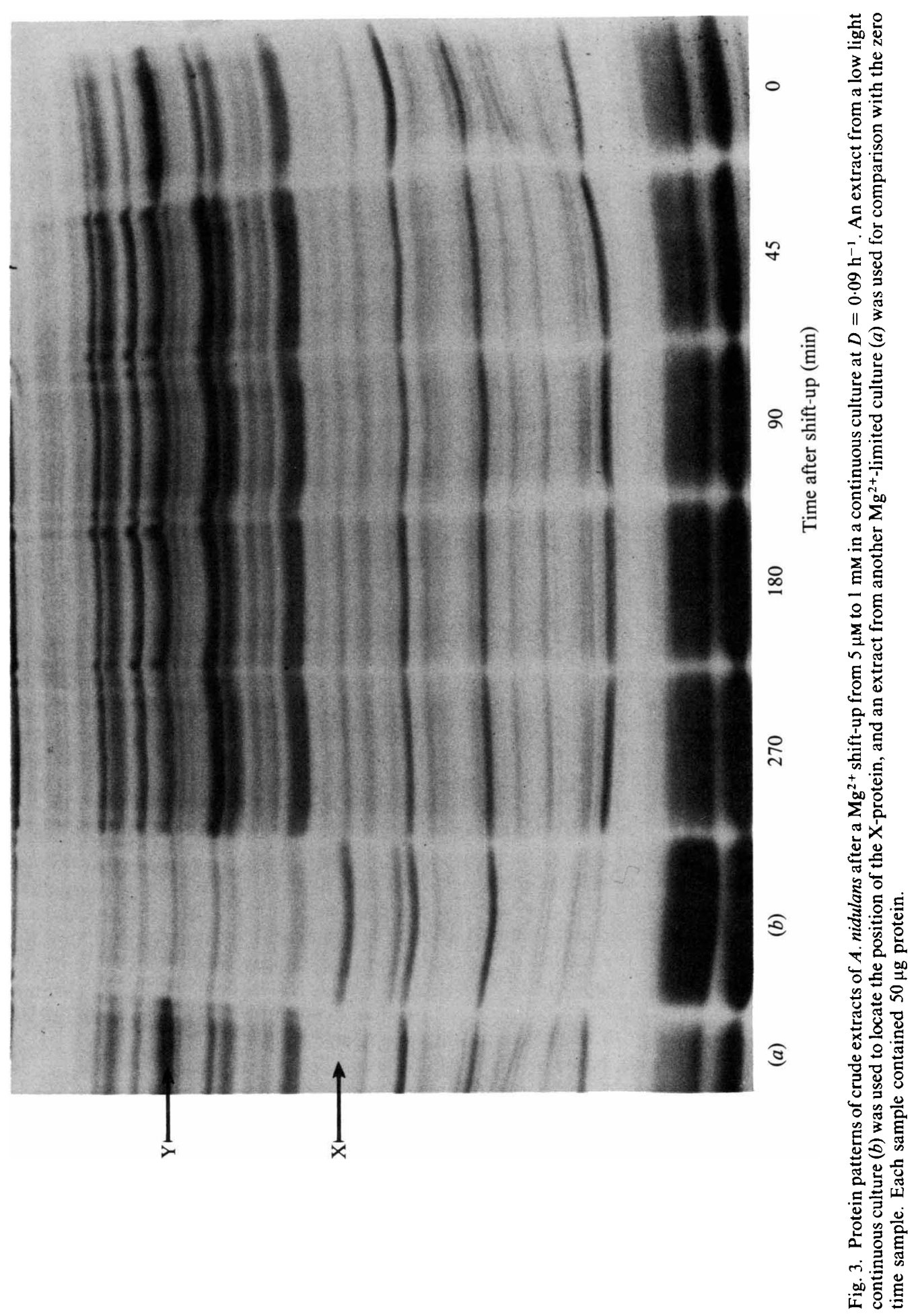




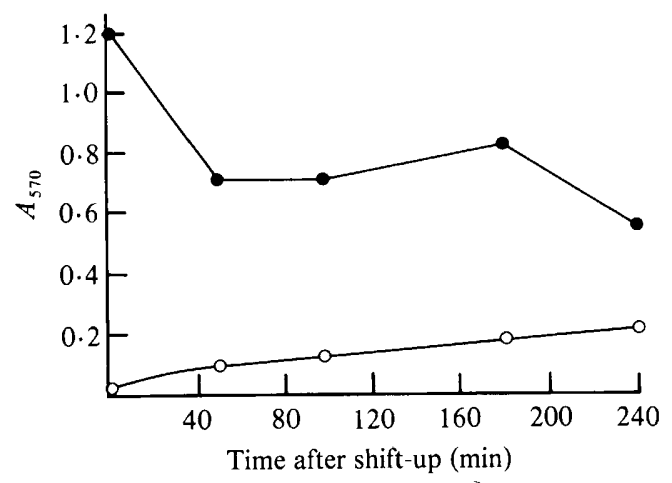

Fig. 4. Relative amount of protein $\mathrm{X}(\mathrm{O})$ and $\mathrm{Y}(\mathrm{O})$ at different times after a $\mathbf{M g}^{2+}$ shift-up from $5 \mu \mathrm{M}$ to $1 \mathrm{~mm}$ in a continuous culture. The amount of protein was determined by scanning the gel shown in Fig. 3 at $570 \mathrm{~nm}$ (see Methods).

shift-up was done in a chemostat (see Methods), it was found (Fig. 3) that the main protein pattern was unaltered while band $\mathrm{X}$-protein started to accumulate and band $\mathrm{Y}$-protein decreased. Since no alterations were found in the other protein bands, Fig. 3 also indicates that the other quantitative differences found between the extracts from $\mathrm{Mg}^{2+}$-limited cells and the non-limited cells (Fig. 1) are not important in connection with cell division.

The rate of increase in $\mathrm{X}$ - and decrease in $\mathrm{Y}$-protein after the $\mathrm{Mg}^{2+}$ shift-up were demonstrated by scanning the gels (Fig. 4).

Lutkenhaus \& Donachie (1979) have identified a cell division protein of the fts $A$ gene in Escherichia coli with a molecular weight of $50 \times 10^{3}$. The synthesis of this protein is required throughout septation and it cannot be re-utilized and is therefore probably used in the process of septation. Cell division in $\boldsymbol{A}$. nidulans might be controlled in the same way as for $E$. coli, since they both have a Gram-negative type of wall. For this reason the Y-protein with a molecular weight of $50 \times 10^{3}$ in $A$. nidulans could have the same functions as the $50 \times 10^{3}$ molecular weight protein in $E$. coli.

There is evidence that initiation of cell division in non-photosynthetic prokaryotes involves accumulation of a 'division protein' (Smith \& Pardee, 1970; Ahmed \& Rowbury, 1971). Results obtained for the cyanobacterium Agmenellum quadruplicatum (Ingram \& Fisher, 1973) indicate that an effector molecule has to accumulate at regions of potential cell division in order to initiate the invagination of cell membrane and cell wall. Even in some eukaryotic organisms, such as Tetrahymena pyriformis (Wheatley et al., 1979) and Physarum polycephalum (Sachsenmaier et al., 1972), cell division has been shown to depend on the accumulation of an initiator protein. The possibility that a 'division protein' has to accumulate in $A$. nidulans in order to initiate cell division therefore seems to be in accordance with results obtained for other organisms. It has also been shown that the induction of a synchronized cell division in $\mathrm{Mg}^{2+}$ limited A. nidulans by a $\mathrm{Mg}^{2+}$ shift-up required protein synthesis (Utkilen, 1982), and Mann \& Carr (1977) have shown that protein synthesis occurring at the termination of DNA replication is necessary for cell division to take place in this organism.

Our preliminary hypothesis, based on the results in the present paper, is as follows. When $A$. nidulans is grown at $5 \mu \mathrm{M}-\mathrm{Mg}^{2+}$, there is inhibition of synthesis of a protein (X) which has to accumulate to a certain concentration before septum formation and cell division can occur. Since these growth conditions do not influence growth or cell mass increase (Utkilen, 1982), the resulting delay in cell division produces filamentous forms of this cyanobacterium. The synthesis of the Y-protein, which might be used during formation of the septum or transverse wall, is not affected by the low $\mathrm{Mg}^{2+}$ conditions used and therefore accumulates when cell division is delayed by low concentrations of this ion.

$\mathrm{Mg}^{2+}$-limited growth in chemostats seems to be a good tool for studying control mechanisms 
in cell division, since alterations in cell division proteins can be induced without altering the main pattern of protein synthesis. The system might also work for other prokaryotes since several of them have been shown to become filamentous during $\mathrm{Mg}^{2+}$-limited growth (Webb, 1949). Cell division in eukaryotes might also be investigated in such a system, since Schizosaccharomyces pombe (Ahluwalia et al., 1978) and Chlorella (Retovsky \& Klasterka, 1961) became enlarged when deprived of $\mathbf{M g}^{2+}$.

The authors thank Dr A. Løvlie, Dr J. Ormerod and cand. real. W. Davies for critical reading of the manuscript.

\section{REFERENCES}

Ahluwalia, B., Duffus, J. H., Paterson, L. J. \& WALKER, G. M. (1978). Synchronization of cell division in the fission yeast Schizosaccharomyces pombe by ethylenediaminetetra-acetic acid. Journal of General Microbiology 106, 261-264.

Ahmed, N. \& Rowbury, R. J. (1971). A temperaturesensitive cell division component in a mutant of Salmonella typhimurium. Journal of General Microbiology 67, 107-115.

Grula, E. A. \& King, R. D. (1971). Changes in the cell membranes of dividing and non-dividing cells of Micrococcus lysodeikticus dis IIp ${ }^{+}$. Biochemical and Biophysical Research Communications 44, 1356-1363.

INGRAM, L. O. \& FisheR, W. D. (1973). Novel mutant impaired in cell division: evidence for a positive regulation factor. Journal of Bacteriology 113, 9991005.

INOUYE, M. \& PARdeE, A. B. (1970). Changes in membrane proteins and their relation to deoxyribonucleic acid synthesis and cell division of Escherichia coli. Journal of Biological Chemistry 245, 5813-5819.

LAEMMLI, U. K. (1970). Cleavage of structural proteins during the assembly of the head of bacteriophage T4. Nature, London 227, 680-685.

Lutkenhaus, J. F. \& Donachie, W. D. (1979). Identification of the ftsA gene product. Journal of Bacteriology 137, 1088-1094.

ManN, N. \& CarR, N. G. (1977). Coupling between the initiation of DNA replication and cell division in the blue-green alga Anacystis nidulans. Archives of Microbiology 112, 95-98.

OAKLEY, B. R., KIRSCH, D. R. \& MoRRIS, N. R. (1980). A simplified ultrasensitive silver stain for detection of proteins in polyacrylamide gels. Analytical Biochemistry 105, 361-363.

O'FARRELL, P. H. (1975). High resolution two-dimensional electrophoresis of proteins. Journal of Biological Chemistry 250, 4007-4021.

Petersen, J. G. L., Kielland-Brandt, M. C. \& Nilsson-Tillgren, T. (1979). Protein patterns of yeast during sporulation. Carlsberg Research Communication 44, 149-162.

Retovsky, R. \& KLASTERKa, I. (1961). Study of the growth and development of Chlorella populations in culture as a whole. $\mathrm{V}$. The influence of the $\mathrm{MgSO}_{4}$ on autospore formation. Folia microbiologica 6, 115-126.

SaChsenmaier, W., Remy, U. \& Plattner-Schobel, R. (1972). Initiation of synchronous mitosis in Physarum polycephalum. Experimental Cell Research 73, $41-48$.

Smith, H. S. \& PARdeE, A. B. (1970). Accumulation of a protein required for division during the cell cycle of Escherichia coli. Journal of Bacteriology 101, 901-909.

UTKILEN, H. C. (1982). Magnesium-limited growth of the cyanobacterium Anacystis nidulans. Journal of General Microbiology 128, 1849-1862.

WEBB, M. (1949). The influence of magnesium on cell division. 2. The effect of magnesium on the growth and cell division of various bacterial species in complex media. Journal of General Microbiology 3, 410-417.

Wheatley, D. N., Rasmussen, L. \& Zeuthen, E. (1979). Analysis of the time of utilization of proteins for the initiation and completion of division in synchronized Tetrahymena pyriformis. Journal of Cell Science 37, 109-116. 